\title{
Michel Foucault
}

- Redaktionelt forord

I dette nummer af SLAGMARK sætter vi fokus på den franske idéhistoriker Michel Foucault (1926-84). Foucault er i dag en af de mest anvendte og citerede teoretikere inden for et væld af discipliner, og han bliver benævnt og benyttet som filosof, sociolog, diskursteoretiker, magtteoretiker og meget, meget andet. Kært barn har som bekendt mange navne. Fokus i dette nummer er dog på Foucault som idéhistoriker og hans brug af historien. For selvom Foucault i dag bruges i mange forskellige kontekster, ikke mindst bruges hans resultater og begreber i mange analyser af aktuelle forhold, så arbejdede han selv først og fremmest med historien. Det var gennem studiet af historien, at han kom frem til de resultater og de undersøgelser, som i dag er blevet så populære. Men Foucault arbejdede med historien på en anderledes måde end historikerne, hvilket i hans samtid også første til en del kontroverser, som eksempelvis hans debat med historikeren Jacques Léonard efter udgivelsen af Overvaigning og straf i 1975, hvortil Foucault skrev teksten "Støvet og skyen", der for første gang er oversat til dansk i dette nummer, og hans kontrovers med Paul Veyne, der endte med, at sidstnævnte blev en af Foucaults fremmeste fortalere som i artiklen "Foucault révolutionne l'histoire" (Foucault revolutionerer historie(n)).

Foucault betegnede imidlertid ikke sig selv som hverken historiker eller idéhistoriker. Da han i 1970 overtog en lærestol på Collège de France fra sin ven og lærermester Jean Hyppolite valgte han titlen: Professor i 'Tankesystemernes historie'. Denne titel er meget sigende for det niveau, hvorpå Foucault bedriver sine (idé)historiske undersøgelser; et sted mellem de abstrakte idéer og de store tænkere på den ene side, og socialhistorien og begivenhedernes niveau på den anden; et sted, hvor tankerne er i system, eller hvor der er en form for logik og konsistens at spore, uden at de nødvendigvis er artikulerede eller eksplicit konsistente; et lidt ubestemmeligt 
sted, hvorfra vi former vores verden og giver den mening, således at vi overhovedet kan agere i den. Et ubestemmeligt sted og et analyse- og undersøgelsesniveau, vi stadig får et større og større indblik i med de fortsatte udgivelser og oversættelser af hans forelæsninger ved Collège de France fra 1970 og frem til sin død, der er blevet udgivet på fransk siden 1997, og som fortsætter med at udkomme og blive oversat til alverdens sprog. I forelæsningsrækkerne får vi, foruden flere udgivelser fra Foucaults hånd, et større indblik i, hvordan han arbejdede og hans egne refleksioner over det, end vi finder $\mathrm{i}$ hans udgivne værker.

Foucault skrev aldrig selv en egentlig metode eller metodologi for den måde, han arbejdede med historien på, der desuden varierede og udviklede sig gennem hans forfatterskab. Dette nummer skal i den forstand ikke læses som et forsøg på at bestemme Foucaults (idé)historiske metode, men derimod som et forsøg på at åbne spørgsmålet om Foucaults tilgang og angive forskellige retninger hvorudfra, man (idé)historisk kan arbejde videre med Foucault og med Foucault kan arbejde videre med (idé)historien. Det har således været vores mål at give nogle afsæt til at kunne arbejde videre med Foucault og ikke blot at tage hans resultater og begreber og anvende dem på nye felter. Det er således vigtigt at understrege, at denne udgivelse på ingen måde er tænkt som en arkivarisk hyldest til en af fortidens kæmper eller en eksegetisk udlægning af en stor mester, men i høj grad forsøger at tage Foucaults egne ord seriøst, når han skriver, at han betragtede sit arbejde som en 'værktøjskasse', og at han "ikke skriver for et publikum, men for brugere" (Foucault 1994: 523-24).

Når man taler om Foucault som idéhistoriker, er det dog vigtigt at tage forbehold. Foucault tog selv eksplicit afstand fra idéhistorien og ønskede ikke at blive forbundet med den. Og så alligevel ikke helt. I Vidensarkaologien fra 1969 skriver Foucault: "Måske er jeg i grunden kun en idéhistoriker. Men en skamfuld eller om man vil indbildsk idéhistoriker. En idéhistoriker, som har villet forny sin disciplin fra grunden" (Foucault 2005: 196). Foucault tog således afstand fra det, man på hans tid kaldte 'idéhistorie', hvilket for det meste var studiet af de store tænkere og deres store tanker, samtidig med han bekendte sig til idéhistorien, hvis blot den blev fornyet fra grunden. Men, hvis han ikke skal kaldes idéhistoriker, 
hvad skal man så kalde ham? Tankesystems-historiker? (Videns)arkæolog? Genealog? Problematiseringshistoriker? Man kunne lave mange bizarre neologismer over titler, Foucault implicit eller eksplicit har givet sig selv gennem de skiftende tematiseringer af sit arbejde. I dette nummer har vi ofte valgt betegnelsen 'idéhistoriker' vel vidende, at det er en idéhistoriker, der vil "forny sin disciplin fra grunden", og som måske selv ville tage afstand fra at blive benævnt 'idéhistoriker'.

Men hvad er det så for en idéhistorie Foucault bedriver? Det er et åbent spørgsmål, og det er netop dette spørgsmål, vi ønsker at åbne med dette nummer. For os at se er der dog altid (mindst) tre elementer på spil i Foucaults idéhistoriske analyser: en praktisk rationalitet eller rationel praksis som genstand; en aktuel kritisk (politisk) ambition; og et igangværende metodeeksperiment.

Den praktiske rationalitet eller rationelle praksis, der undersøges, placerer sig i et ikke helt identificérbart mellemfelt, som ligger et sted i mellem filosofi, litteratur, videnskabelige teorier, videnskabelige praksisser, institutionelle teknikker, praktiske manualer, pamfletter og traditioner o.l.. I Galskabens historie (1961) er det f.eks. ikke den gale, anstalterne, straffe- og behandlingspraksisserne eller opkomsten af psykiatrien, som Foucault vil undersøge. I stedet er undersøgelsesgenstanden 'den vestlige erfaring af galskaben', som den ændrer sig gennem historien, og som bliver til forholdet mellem fornuft og ufornuft (galskab). Det, Foucault undersøger, er således snarere, hvordan en særlig måde at tænke på opstår, en særlig logik, som på et eller andet tidspunkt bliver naturlig for os, således vi tænker, at det ikke kunne have været anderledes. Genstanden for Foucaults undersøgelse er altså en erfaring eller et problem (problemet med galskaben), således som den optræder i produktionen af en type rationalitet. Eller som Foucault selv kalder det: Historie over problematiseringer, hvormed han mener forskellige måder at løse problemer på og stille spørgsmål på. Foucault undersøger således på mange måder, hvordan det blev muligt at stille visse spørgsmål og at løse visse på problemer på visse måder på bestemte tidspunkter i historien. Og hvordan disse måder at stille spørgsmål og løse problemer på blev naturlige for os.

Det er på mange måder den samme type eller art af genstand, man finder i Foucaults øvrige arbejde fra Klinikkens fodsel (1963), 
hvor Foucault vil undersøge 'mulighedsbetingelserne for den medicinske erfaring i moderne tid', mens det i Ordene og tingene (1966) ikke så meget er humanvidenskaberne som sådan, som det er 'den rene erfaring af orden og dens værensmåder', der er genstanden. I Overvågning og straf (1975) handler det ikke om fængselsvæsenets eller straffens opkomst som institution, men snarere om, hvordan tænkningen om straffen og afstraffelsen overgår til at blive opdragelsen af den enkelte til at være et produktivt individ. Det samme kan også siges forelæsningsrækkerne Sikkerhed, territorium, befolkning (197778) og Biopolitikekens fodsel (1978-79). Her handler det netop ikke om staten som institution, entitet og identitet, men derimod om den 'praktiske rationalitet' og den 'rationelle praksis' i forhold til regeringen af mennesker, som også var udfoldet tidligere i forbindelse med Galskabens historie, Klinikkens fodsel og Overvågning og straf. I forelæsninger fra 1978 og 1979 undersøges regeringen af menneskene i modsætning til tidligere på et overordnet politisk og regeringsmæssigt niveau, og det er dette eksplicitte spørgsmål om regering Foucault efter $1979 \mathrm{i}$ højere og højere grad begyndte at undersøge som selvledelse og selvregering.

Men hvorfor undersøge netop én rationalitet frem for en anden? Her må man søge svaret et andet sted, nemlig i de aktuelle spørgsmål, der nager Foucault og hans samtid. Den aktuelle kritiske (politiske) ambition varierer i løbet af Foucaults forfatterskab, men den synes at være på spil fra de tidligste udgivelser om galskab, psykologi og mentale patologier til de sidste udgivelser om seksualitetens historie og den her genoptrykte artikel om oplysningens projekt: "Hvad er oplysning?" I Overvågning of straf bemærker Foucault således, at dét at "straffene i al almindelighed og fængslet i særdeleshed beror på en politisk teknologi for kroppen, er det måske mindre historien end nutiden, der har lært mig" (Foucault 2002: 44). Denne forestilling om nutiden som afsæt for de idéhistoriske analyser går samtidig igen i en formulering, som Foucault benyttede sig af flere gange i sit forfatterskab, men som han først for alvor tematiserede i de seneste år, nemlig idéen om en 'samtidshistorie'. Foucault er utvetydig i sin ambition med en sådan samtidshistorie. Hvor den 'normale' historie forsøger at genskrive fortiden ud fra nutiden og er 'besat af en søgen efter oprindelse', som Foucault skrev det i teksten "Nietzsche - genealogien, historien", er samtidshistoriens 
ambition at genskrive nutiden ud fra fortiden, hvor det netop ikke drejer sig om at finde oprindelsen, men om brud, variationer og forandringer (men også kontinuitet) i måden at tænke på. Det vil sige, historien med dens tænkning og praksisser fungerer for Foucault ikke som et antikvarisk skatkammer, historikeren passivt kan beundre. De kilder, samtidshistorikeren beskæftiger sig med, skal i stedet have lov til at blande sig i nutiden. Den skal vise os, hvordan vi tænker, hvad vi tager for givet og hvorfor. Og samtidig skal de give os muligheden for at bryde med den dominerende rationalitet og tænke anderledes. Der er således et umiskendeligt aktivistisk element i Foucaults idéhistorie, som udspringer fra aktuelle bekymringer, og som har ambitioner om at intervenere $\mathrm{i}$ aktuelle begivenheder.

Endelig manifesterer en sådan tilgang sig - på den ene side blotlæggelsen af den herskende vanetænkning og på den anden side søgningen efter muligheden af at tænke og handle anderledes - i en række metodiske eksperimenter, eller måske snarere, i en evig eksperimenteren fra Foucaults side. Foucaults tænkning hviler aldrig, det er aldrig et spørgsmål om blot at undersøge et nyt objekt med de allerede givne analysekategorier, og især i bøgerne kan det indimellem være svært at finde ud af, hvad det egentlig er, Foucault overhovedet undersøger eller prøver at sige. Hvad er der præcis på spil i forskellen mellem den arkæologiske og den genealogiske analyse? Hvori består forskellen mellem at tilgå historiens idéer gennem kategorier som hhv. 'epistemet', 'det historiske apriori', 'dispositivet', 'sikkerhedsforanstaltninger' og 'guvernementalitet'? I hvilken grad kan man tale om 'panopticisme', og hvorledes forholder den sig til hhv. disciplinærmagt og studiet af magtens mikrofysik? Det er næppe så vigtigt ( $\mathrm{og}$ vil heller ikke blive diskuteret nærmere i dette nummer) og givetvis også en smule overkonstrueret, hvis man forsøger at lave en præcis udredning af Foucaults analysekategorier og deres eksakte forhold til hinanden. Foucaults kategorier bliver til i takt med analysen af empirien, og det er ofte lige så meget opdagelsen af kategorien som analysen af materialet, der interesserer ham. Eksempelvis afslutter han de tretten forelæsninger (knap 400 sider) Sikkerhed, territorium, befolkning ved at sige, at "alt, hvad jeg ville udrette i år, var intet andet end et lille metodeforsøg" - et lille metodeforsøg, der vel at mærke affødte begrebet 'guvernementali- 
tet', som i dag hører til blandt de mest brugte og diskuterede kategorier indenfor både human- og samfundsvidenskaberne. Der er dermed en klar forbindelse mellem Foucaults overordnede tilgang og hans konstante metodeforsøg. Gennem de nye kategorier bliver det netop muligt for os at inddele og se verden på en anden måde, og hans arbejde med forskellige emner og med forskellige kategorier skaber en konstant om- og genvurdering af selve måden at arbejde på.

Med denne udgivelse håber vi at bringe nogle af disse temaer og tilgange, man vil finde i Foucaults idéhistorie, på bane, så de forhåbentligvis kan inspirere til nye analyser, der tvinger os til at tænke anderledes over både historien, vores samtid og os selv.

Vi starter temaet med en tekst fra Michel Foucaults egen hånd, nemlig "Støvet og skyen" (La poussière et le nuage), som for første gang bringes i en dansk oversættelse. Teksten er Foucaults svar på en kritik, der blev rejst af historikeren Jacques Léonard i forbindelse med Foucaults Overvagning og straf i 1975. I artiklen forsøger Foucault at forklare forholdet mellem filosofien og historien og beskriver den særlige måde, hvorpå han bedriver historie og går til historien - en tilgang, der netop er anderledes end den rent 'historiske'. Artiklen kan dermed læses som en slags metodeskrift over Overvagning og straf, der samtidig knytter an til Foucaults mere generelle overvejelser over den type af (idé)historie, han bedriver.

Derefter går vi til Kasper Villadsens og Mads Peter Karlsens "Foucault - maoismen, genealogien", som lokaliserer kilder til Foucaults genealogiske metode. Sædvanligvis tilskrives Nietzsche den afgørende betydning for Foucaults genealogi, bl.a. i kraft af Foucaults egen henvisning til Nietzsche i "Nietzsche - genealogien, historien", men som denne artikel demonstrerer, er der grund til at give maoismen mere - hvis ikke den afgørende - plads blandt Foucaults inspirationskilder. Artiklen undersøger betydningen af den maoistiske undersøgelsesmetode bl.a. i kraft af Foucaults engagement i Groupe d'information sur les prisons (GIP) og indgår samtidig $i$ en bredere diskussion af Foucaults forhold til marxismen. Disse argumenter bliver desuden relateret til Foucaults genealogiske metode i forelæsningsrækken fra 1976, "Samfundet må forsvares".

I artiklen "At genplacere den moderne state - guvernementalitet 
og de politiske idéers historie" forsøger den tyske filosof Martin Saar at læse de to forelæsninger, som Foucault selv kaldte 'en historie om guvernementaliteten', Sikkerhed, territorium, befolkning (197778) og Biopolitikekens fodsel (1978-79), som et 'metodologisk løfte' og forsøger derudfra at rekonstruere en foucauldiansk tilgang til de politiske idéers og den politiske tænknings historie. Denne tilgang bliver derefter sat over for andre og mere traditionelle tilgange til det samme emne, såsom traditionel idéhistorie og intellektuel historie og begrebshistorie, og der argumenteres for, at Foucaults tilgang tilbyder en helt særlig måde og et helt særligt alternativ til at studere den politiske idéhistorie på, som på mange måder er de etablerede perspektiver overlegen.

Vi fortsætter det politiske spor i udgivelsens fjerde artikel: "Kongen hersker, men regerer ikke". Her benytter Nicolai von Eggers og Mathias Hein Jessen den italienske idéhistoriker Giorgio Agambens bestræbelser på at genoplive de idéhistoriske aspekter af Foucaults undersøgelser af regeringsrationaler (guvernementalitet) til at udfolde, hvad der kendetegner Foucaults idéhistorie over guvernementaliteten, og det specifikke niveau hvorpå Foucaults undersøgelser af stat, politik og regeringen af mennesker finder sted. For Foucault gælder det om at ophæve staten som en fast og given institution og entitet for i stedet at analysere staten som 'en måde at regere på’, 'en måde at tænke på’ og som en særlig regeringsmæssig rationalitet og en refleksion over 'dét at regere'. Artiklen forsøger dermed at pege på, hvordan man kan undersøge staten og dens idéhistorie med Foucault.

Nogle af de kendetegnende idéhistoriske træk ved Foucaults arbejde bliver yderligere diskuteret i Mathias Hein Jessens interview med den italienske retshistoriker Paolo Napoli. Her diskuteres bl.a. hvordan man kan bedrive retshistorie ved at bruge Foucault, og hvad der kendetegner et særligt foucauldiansk 'take' på retshistorien. I interviewet argumenter Napoli særligt for, hvad han kalder: "De retslige, administrative og normative dispositivers autonomi". Hermed mener Napoli en særlig logik, teknik og strategi, som kendetegner det retslige og det normative, og som ikke kan reduceres til det retsliges funktionalitet eller dets brug som et suverænitetsinstrument, men som netop får sin særlige karakter i kraft af dets autonomi, og hvordan det bliver taget op i forskellige kontekster og 
bruges med og mod herskende institutioner og praksisser. Undervejs $\mathrm{i}$ interviewet kommer Paolo Napoli omkring sin egen forskning med den teologiske herkomst af moderne forestillinger om administration og forvaltning, ligesom han forholder sig kritisk til Foucault-eksegese og udlægninger af Foucault som liberalist.

I denne udgivelses sjette artikel sætter Jonas Lillebø og Bjørnar Mortensen Vik fokus på Foucaults brug af historien med udgangspunkt i nogle nyere Foucault-læsninger, der i højere grad åbner op for at forstå den gensidige og dynamiske relation, der er mellem det teoretiske og det empiriske/historiske i Foucaults forfatterskab. Artiklen argumenterer således for, at det i Foucaults forfatterskab er arbejdet med det historiske 'fremmede materiale' som skaber bevægelsen i hans tænkning og som kræver, at han hele tiden udvikler sine teoretiske begreber, og at det historiske materiale netop ikke bare bliver brugt som eksempler på hans teoretiske begreber. Artiklen forsøger at demonstrere en 'brug af historien' i Foucaults arbejde, som ikke skal forstås instrumentelt, men generativt og retroduktivt.

Dernæst vender vi blikket mod Michel Foucaults refleksioner over mennesket og dets forhold til sig selv som et historisk væsen $\mathrm{i}$ "Hvad er oplysning?". Foucaults artikel genstiller Kants spørgsmål om, hvad oplysningen er, ved at undersøge, hvad moderniteten er, og for Foucault er moderne filosofi netop en filosofi, der prøver at besvare spørgsmålet: Hvad er oplysning? Selvom der er forskel på Kants tid og vor egen, er mennesket, siden Kant forsøgte at besvare spørgsmålet om oplysning, kendetegnet ved at forstå sig selv som tilhørende en særlig epoke. Mennesket har altså et historisk forhold til sig selv, og moderne filosofi er kendetegnet ved en særlig holdning, eller 'ethos', der er en kritik af samtiden og den historiske epoke, mennesket befinder sig i. Teksten var en af de sidste, Foucault udgav før sin død i 1984, og den fik stor betydning for hans reception uden for Frankrig.

Receptionen af Foucault i Tyskland er afsættet for den næste artikel, som er Nicolai von Eggers' interview med den tyske politolog Thomas Biebricher, "Den neoliberale guvernementalitet, biopolitik og teologi“". Interviewet starter med en diskussion af receptionen af Foucault i Tyskland, særligt i gennem Jürgen Habermas’ divergerende syn på Foucaults tænkning. Foucault er i dagens 
Tyskland en af de mest læste tænkere, når det kommer til politisk, kritisk forskning, særligt inden for de såkaldte 'guvernementalitetsstudier', som undersøger moderne og aktuelle regeringsrationaler og -strategier. Således også Biebricher, der igennem interviewet diskuterer neoliberalisme og dens opkomst som en særlig form for rationalitet og strategi, og Foucaults betydning for undersøgelsen af dette felt.

Temanummeret slutter af med Anders Dræby Sørensens artikel "Eksistensens nøgne hjerte og tragiske splittelse". Heri undersøger Dræby afsættet for den tidlige Foucaults tænkning, ikke mindst inspirationerne fra den schweiziske psykiater Ludwig Binswanger og dennes Dasein-analyse og således også inspirationen fra Martin Heidegger på den ene side og inspirationen fra eksistentialismen (særligt den franske med Jean-Paul Sarte og Maurice MerleauPonty) på den anden. Sørensen argumenterer for, at det ikke er i et radikalt brud med sine ungdommelige interesser, at Foucault vendte sig mod historien, men nærmere som en kritisk radikalisering af dem. Artiklen giver således et nyt og interessant indblik i, hvorfor Foucault begyndte at beskæftige sig mere indgående med historien.

I intermezzoet "Hjernen i Immanuel Kants senværk og Catherine Malabous samtidskritik“" undersøger Steen Nepper Larsen argumenterne i hhv. Immanuel Kants senværk Anthropologie in pragmatischer Hinsicht (1798) og Catharina Malabous Que faire de notre cerveau? (Hvad skal vi gøre med vores hjerne?) fra 2004. Artiklen diskuterer således argumenterne bag disse to modsatrettede 'positioner' i et bredere filosofisk antropologisk perspektiv og spørger ind til grænserne for Kants tilgang til hjernen og til, hvorvidt Malabous normative projekt tager sit udgangspunkt i voluntarisme.

Som sædvanlig rundes temanummeret af med en anmeldersektion. Ellers er der intet andet tilbage end at ønske god fornøjelse!

På redaktionens vegne

Nicolai von Eggers og Mathias Hein Jessen 


\section{Litteratur}

Foucault, Michel (1994): Dits et écrits, vol. 2, Paris: Éditions Gallimard.

Foucault, Michel (1998, [1976]): Viljen til viden - seksualitetens historie 1, Frederiksberg: Det lille Forlag.

Foucault, Michel (2000, [1963]): Klinikkens fodsel, København: Hans Reitzels Forlag.

Foucault, Michel (2002, [1975]): Overvågning og straf, Frederiksberg: Det lille Forlag.

Foucault, Michel (2003, [1972/1961]): Galskabens historie i den klassiske periode, Frederiksberg: Det lille Forlag.

Foucault, Michel (2005, [1969]): Vidensarkecologien, Aarhus: Philosophia.

Foucault, Michel (2006, [1966]): Ordene og tingene, Frederiksberg: Det lille Forlag.

Foucault, Michel (2008, [2004]): Sikkerhed, territorium, befolkning - forelasninger ved Collège de France 1977-78, København: Hans Reitzels Forlag.

Foucault, Michel (2009a, [2004]): Biopolitikekens fodsel-forelasninger ved Collège de France 1978-79, København: Hans Reitzels Forlag.

Foucault, Michel (2009b, [1971]): "Nietzsche - genealogien, historien" i Michel Foucault, Talens forfatning, København: Hans Reitzels Forlag, s. 57-82. 